\title{
Öğretmenlerin Hesap Verebilirlik Çevreleri: Teorik Bir Çözümleme
}

\author{
DOI: $10.26466 /$ opus.559784 \\ * \\ Coşkun Erdağ \\ * Dr. Öğr. Üyesi, Aksaray Üniversitesi, Eğitim Fakültesi, Aksaray / Türkiye \\ E-Posta: coskunerdag79@gmail.com ORCID: $\underline{\text { 0000-0002-6173-6340 }}$
}

Öz

Bu araştırmada, örgütsel yaşam içerisinde hesap verebilirlik baskılarının çalışanların hesap verebilirlik inançların nasıl şekillendirdiğine yönelik ulusal ve uluslararası alanyazın temelli teorik bir çerçeve oluşturulması ve Türkiye'de öğretmenlerin hesap verebilirliğine ilişkin doğurgalarının ortaya konulması amaçlanmaktadır. Literatür incelemesi sonucu, çalışanların hesap verebilirlik inançlarını şekillendiren etkilerden biri olarak hesap verebilirlik ortamların (i) hesap verebilirlik baskılarının kaynağı, (ii) baskıları amacı veya odağı, (iii) hissedilen yoğunluğu ve (iv) yüklenilen sorumluluğun ehemmiyeti olmak üzere birbirleriyle etkileşimli dört temel boyuttan oluştuğu sonucuna ulaşılmıştır. Çalışanlar üzerinde bürokratik, sosyal ve mesleki çevrelerin hangi amaçla, hangi koularda, ne kadar yoğun baskı uyguladıklarının yanı sıra, baskı konularının çalışanlar için ne kadar önemli olduğu da çalışanların hesap verebilirlik inançlarının düzeyini belirlemektedir. Buradan hareketle, Türkiye'de öğretmenlerin hesap verebilirliklerini yükseltmek amacıyla formal ve informal mekanizmaların oluşturulması ve işlerlik kazandırılması önerilmektedir. Bu kapsamda, formal olarak öğretmen ve yöneticilerin yeterlilikleri, seçimi, mesleki gelişimleri, mesleki etik ve davranışlara ilişkin kendilerinden neler beklendiğini açık ve net olarak yazılı bir şekilde ortaya koyan ölçülebilir, ulaşılabilir ve birbirleriyle uyumlu davranış ve performans standartlarının belirlenerek uygulamaya konulması gerekmektedir. Ayrıca, yönetim bilgi sistemleri başta oılmak üzere farklı paydaşlardan ve kaynaklardan öğretmen ve öğrencilerin performanslarına ilişkin veri toplanılmalı, verilere dayalı olarak öğretmen performans değerlendirmesi yapılmal, iyi işler ödülledirilip desteklenirken, olumsuz davranışların düzeltilmesi sağlanmalıdır. Öte yandan, informal olarak üst yönetim birimleri doğru davranışları cesaretlendiren ve yanlış olanlardan caydırıcı bir kontrol söylemi ve kültürü geliştirmeli, kontrole olan ihtiyacı ön plana çıkarmalı, kontrolün gerekli ve vazgeçilmez bir süreç olduğu anlayışını hem sözleriyle hem de eylemleriyle herkese göstermelidir.

Anahtar Kelimeler: Öğretmen hesap verebilirliği, Hesap verebilirlik ortamı, Öğretmen inançları, Bireysel hesap verebilirlik. 


\title{
Teachers Accountability Environments: Implications for Turkish Schools
}

$*$

\begin{abstract}
In this study, it is aimed to create a theoretical framework based on national and international literature on how the accountability pressures shape employee feelings of accountability and to discuss its implications for teacher accountability in Turkey. As a result of the literature review, one of the factors that shape the accountability beliefs of employees involves four interacting dimensions: (i) Acountability source, (ii) accountability purpose or focus, (iii) the intensity felt of the accountability pressures, and (iv) the importance of the accountability issue perceived by the employees. The review summarizes that in addition to whether bureaucratic, market and professional environment exert some pressure or not on the employees and the focus of the pressures, if any, the importance of accountability issues for the employees determines the level of employee accountability beliefs. From here, it is suggested that formal and informal mechanisms should be established and kept functioning in order to increase the felt accountability of teachers in Turkey. To this end, as a formal way, there should set up measurable, achievable and consistent behavior and performance standards on their qualifications, selection, professional development, professional ethics and proper behavior which clearly reveal what is expected of teachers and managers at work. In addition, data on teacher and student performance should be collected from different stakeholders and sources, especially by Management Information Systems, and teacher performance evaluation should be performed based on data, and the correction of negative behaviors should be ensured while rewarding and supporting good work. Informally, besides, senior management units should develop a control discourse and culture that encourages the right behaviors and discourages the wrong ones, bring the need for control to the fore, show the understanding that control is a necessary and indispensable process, both in words and actions.
\end{abstract}

Keywords: Accountability felt, Teacher accountability, Accountability environment, Teacher beliefs, Turkey 


\section{Giriş}

İster en basit haliyle ikili ilişkilerde olsun, isterse belirli bir örgütsel çatı altında olsun, sosyal hayatta birçok farklı skandalın gerçekleştiğini, yasalara aykırı, ikili anlaşmalara ters birçok olumsuz davranışın sergilendiğini neredeyse her gün duyuyor ve görüyoruz. Bazen medyanın ünlüleri, sporcular, siyasetçiler bazen de şirket çalışanlarının veya kamu görevlilerinin hiç hesap vermeyecekmiş gibi sergiledikleri çeşitli davranışlara tanık oluyoruz (Hall, Bowen, Ferris, Royle ve Fitzgibbons, 2007). Bu durum, verimli, etkili ve adaletli bir şekilde öğretim hizmeti sunmayı amaçlayan ve aynı zamanda sosyal ve açık bir sistem olan eğitim sistemleri ve işleyişleri için de geçerlidir. Öğretmenlerin yanlızca okul müdürleri, orta ve üst düzey yöneticilerle değil, veliler, öğrenciler, meslektaşları gibi diğer okul paydaşlarıyla olan sosyal etkileşimlerinde de etik ve yasa dışı olaylar yaşanmaktadır. Tüm bu olumsuzluklar yalnızca kamuoyunda değil, hem akademik çevrede hem de medyada öğretmenlerin hesap verebilirliği konusunda endişe yaratmış, medyanın ve akademinin dikkatlerini öğretmenlerin hesap verme tutumlarına çekmiştir.

Alanyazındaki çalışmalar, hesap verebilirlik olgusunun sosyal yaşamın düzeninin sağlanması ve sürdürülmesinde en temel öğelerden biri olarak ele alındığını göstermektedir (Hall, Frink, Ferris, Hochwarter, Kacmar, ve Bowen, 2003; Tetlock, 1985; 1992). Sosyal yaşam boyutuyla ele alındığında, hesap verebilirlik, bireylerin kendi yaşantılarındaki eylem özgürlüğüne diğerlerinin ortaya koyduğu haklı tepkilerle bir sınır getirmektedir (Mitchell, Hopper, Daniels, George-Falvy, ve Ferris, 1998). Örgütsel yaşam boyutuyla bakıldığında, Monks ve Minow (1991) günümüz modern dünyasında büyük ölçekli en başarılı örgütlerin başarısını hesap verebilirlik uygulamalarına dayandırmaktadır. Hesap verebilirlik, örgüte ait eylemlerin koordinasyonunu, örgütteki süreçlerin ve sonuçların kontrolünü sağlamakta, örgütün verimli ve etkili bir şekilde işlemesine imkan sağlamaktadır (Enzele ve Anderson, 1993; Frink ve Klimoski, 1998; Yarnold, Muesur, ve Lyons, 1988). Kontrol ve düzen işlevine ek olarak, Plato hesap verebilirliğin aynı zamanda ilişkilerde adaletin de temeli olduğunu savunmaktadır (Hall et.al, 2007). Örgütlerde hayat bulan formal veya informal hesap verebilirlik mekanizmaları da, bazı olumsuz sonuçları rapor 
edilse de, istenmeyen davranışları engellemede başarılı olmuştur (Mitchell et al., 1998). Bu açılardan bakıldığında, sosyal ve örgütsel yaşamda düzen ve adaletin sağlanmasına önemli katkı sunan hesap verebilirlik olgusunun bireylerde geliştirilmesi büyük önem arz etmektedir. Bunun nasıl gerçekleştirileceğine yönelik yapılan çalışmalarda, çalışanların içinde bulundukları hesap verebilirlik ortamlarının çalışanların hesap verme inançlarını şekillendirdiği bildirilmektedir (Ferris, Mitchell, Canavan, Frink, ve Hopper, 1995; Frink ve Klimoski, 1998; Hall, Blass, Ferris, ve Massengale, 2004; Hall et.al, 2007). Bu bağlamda, özellikle örgütsel yaşamda çalışanları çevreleyen hesap verebilirlik ortamlarının niteliği ve niceliğinin, aynı zamanda bireylerin hesap verme tutum ve inançlarını nasıl şekillendirdiğinin ortaya konulması önemlidir. Örgütsel yaşama hesap verebilirlik çerçevesinden bakılması çalışanların davranışlarını görme, onları anlama ve davranışı işlevsel olana doğru yönlendirmeye imkan sağlayacaktır. Bu anlamda, iş görenlerde hesap verebilirlik inançlarını çalışma ortamlarının nasıl şekillendirdiği bilgisi iş yaşamında sürekli olarak karşımıza çıkan yönetişim ve etik tartışmalarında planlamacılara ve araştırmacılara ışık tutma potansiyeline sahiptir. Bu bilgi çalışanlara ise üzerlerindeki farklı hesap verebilirlik baskılarını tanımaları, bu baskılara kendilerini hazırlamaları ve onları yönetebilme becerisi kazandıracaktır (Hall et al., 2007). Türkiye'de daha çok kamu yönetimi, sağlık, güvenlik ve eğitim yönetimi özelinde geliştirilen hesap verebilirlik tartışmalarında çalışanların hesap verebilirlik inançlarına ilişkin çalışmalara çok az rastlanmaktadır. Yapılan çalışmalar daha çok örgütsel yaşamda kim, kime, hangi konuda, nasıl hesap vermeli soruları üzerine yoğunlaşmakta, farklı bireysel ve kurumsal faktörlere göre görüşlerdeki farklılaşmalar ile mevcut uygulamalar ortaya konulmaktadır (Bülbül, 2011; Çiçekli, 2016; Erdağ, 2017; Erdağ ve Karadağ, 2017; 2018; Erkoşar, 2013; Kantos, 2010; Küçükaycan, 2018; Özen, 2011; Özcan, 2011; Salduz, 2013; Türkoğlu, 2015; Yıldırım ve Yenipınar, 2019). Buradan hareketle, bu çalışmada örgütsel yaşam içerisinde hangi özelliklerin çalışanların hesap verebilirlik inançlarını nasıl şekillendirdiğine yönelik ulusal ve uluslararası alanyazın temelli teorik bir çerçeve oluşturulması amaçlamaktadır. Bu kapsamda, (i) çalışanları hesap verebilir kılan bir çalışma ortamının temel özellikleri nelerdir?, (ii) bu özelliklere sahip bir çalışma ortamı nasıl yapılandırılmalıdır sorularına cevap aranmaktadır. Bu kapsamda, ulusal ve uluslararası veritabanlarında 
(ISI Web of Science, ERIC, PsycINFO, TR Dizin, YÖK Tez vb.) "hesap verebilirlik", "accountability", "teacher accountability" ve "öğretmen hesap verebilirliği" gibi anahtar kelimelerle kaynak taraması yapılmış, elde edilen veriler analiz edilerek bütüncül bir değerlendirme yapılmıştır.

\section{Hesap Verebilirlik Kavramı}

Literatür incelendiğinde, terim anlamı olarak hesap verebilirliğin batı dillerinde hesap yapmak, betimlemek, açıklamak, savunmak, doğrulamak ve sorumluluk gibi farklı anlamlarda kullanıldığı, kavramın farklı bağlamlarda farklı şekillerde ele alındığı görülmektedir. Örgütsel açıdan yaklaşıldığında hesap verebilirlik yetkinin uygun kullanımını sağlayan roller ve kurallar, belirsizlikler ve beklentiler ile başa çıkabilmek için formal veya informal mekanizmaların oluşturulması olarak ele alınmaktadır (Bovens, 2007; Dubnick, 2002; Jordan, 2011, Koppell, 2011; Kuchapski, 2001; Leithwood ve Earl, 2000; Møller, 2009; Schillemans ve Bovens, 2011; Wagner, 1989). Başka bir ifadeyle, hesap verebilirlikten örgütlerin çeşitli paydaşların beklentileri doğrultusunda belirlenen politika ve uygulamaların izlenilmesi, yürütülmesi ve uygulamaya konulması konusundaki örgütsel mekanizmalar kastedilmektedir. Aynı zamanda hesap verebilirlik, örgütsel yaşamda bir kontrol sistemi, ya da örgütsel standartlara uyumu sağlayan ödül veya ceza sistemi olarak anlaşılmaktadır (Frink ve Ferris, 1998). Kamu hizmetlerinin üretimi ve sunumu dikkate alındığında, hizmet üretenle hizmeti kullananlar arasında güçlü bir güven ortamının oluşturulması, bürokrasinin daha demokratikleşmesi, verimli ve etkili bir işleyişin teminini amaçlayan hesap verebilirlik vurgusu (Balc1, 2003), ürettiği sonuçlar ve durum göz önüne alındığında da bir değerler sistemi, aynı zamanda bu sonuçları üreten sosyal bir mekanizma olarak anlaşılmaktadır. Hesap verebilirlik, Amerika'da kamusal yaşamı düzenleyen bireysel ve örgütsel bir erdem, Avrupa'da ise demokrasinin temeli olan sosyal bir mekanizma olarak ele alınmaktadır (Aucoin ve Jarvis 2005; Bovens, 2007; 2010; Day ve Klein, 1987; Lerner ve Tetlock, 1999; McCandless, 2001; Mulgan, 2003; Philp, 2009; Romzek ve Dubnick, 1998; Scott, 2000).

Hesap verebilirlik kavramı aynı zamanda sosyal sistemleri bir arada tutan bir tutkal olarak kavramlaştırılmaktadır. Bireylerin aldığı karar ve sergiledikleri eylemlerin haklılığının sorgulanmadığı bir ortamda sosyal 
düzenin oluşturulması ve onun sağlıklı bir şekilde işletilmesi de imkan dahilinde değildir (Tetlock, 1992). Frink ve Klimoski (2004) ise, hesap verebilirliği tanımlama amaçlı yaklaşımların (i) ikili ilişkiler ve (ii) değerlendirme ve dönüt olmak üzere iki temel tema etrafında yoğunlaştığını belirtmektedir. Hesap verebilirlik ilişkisinin taraflarından biri olan üst (principal, audience, hesap soran) bir kişi veya birçok kişi olabilir. Bunlar, belirli bir sebepten dolayı astı gözleyen, izleyen ve değerlendiren taraftır. İkili ilişkinin diğer tarafı olan ast ise (agent, hesap veren) kararları ve eylemleri değerlendirilen taraftır (Adelberg ve Batson, 1978; Cummings ve Anton, 1990). Bunlara ek olarak, Schlenker ve Weigold (1989) bireyin kendisinin hem hesap soran hem de hesap veren olarak da kurgulandığı, kendi eylemlerini kendi standartlarına göre değerlendirdiği kendi kendine hesap vermenin de bir hesap verebilirlik ilişkisi olduğunu ileri sürmektedir. Bu bağlamda, bireysel hesap verebilirlik, bireyin yükümlülüklerine olan içsel bağlığı olarak ele alınan sorumluluk kavramı ile çok yakın bir anlama sahip olmakla beraber, sorumluluk kavramının bir adım ötesine geçerek, standartları yakalama ve ilgili birimlere raporlama yönündeki bağlılık olarak ele alınmaktadır (Rosenblatt, 2017). Hesap verebilirlik en temel anlamıyla, bireylerin kendi kararlarını ve eylemlerini savunabilir kılmaktır (Hall et al., 2009). Değerlendirme ve dönüte odaklanan diğer yaklaşımda ise, astın davranışları gözlenir ve izlenir, belirlenen bazı davranışlara ilişkin asttan bir açıklama istenir, eyleminin haklılığını göstermesi beklenir ve ortamda buna yönelik beklenti oluşturulur. Bu süreçte astın davranışını etkileyecek asıl unsur ödül ve cezaların kullanımıdır (Mitchell, 1993).

\section{Bireysel Hesap Verebilirlik}

Birey düzeyinde hesap verebilirliğini açıklamaya çalışan temel iki ana yaklaşımdan ilki hesap verebilirliği dışsal koşulların ürettiği bir etki olarak kavramlaştırırken, ikincisi içsel bir dünya, ruh hali veya bir zihniyet olarak ele almaktadır (Frink ve Klimoski, 1998; Hall, Frink ve Buckley, 2017). Kavrama diş çevre ve koşullar açısından bakıldığında, hesap verebilirlik bireyin maruz kaldığı etkilerin davranışını nasıl şekillendirdiği üzerine eğilmektedir (Cummings ve Anton, 1990; Fandt ve Ferris, 1990; 
Mero ve Motowidlo, 1995). Bireyin eylemlerinin meşru bir diş güç tarafından incelenmesi, buna bağlı olarak ödüllendirilmesi ve yaptırım uygulanması sürecini içermektedir (Frink ve Ferris, 1998; Hall ve Ferris, 2011). Hesap verebilirlik aynı zamanda bireylerin inançları, duyguları ve eylemlerine ilişkin diğerlerine haklılığını göstermesi yönündeki dolaylı veya direk beklentiler olarak da kavramlaştırıldığı görülmektedir (Lerner ve Tetlock, 1999; Scott \& Lyman, 1968; Semin \& Manstead, 1983; Tetlock, 1992). $\mathrm{Bu}$ anlamda, hesap verebilirlik, meşru güç odaklarının bireylere yüklediği beklentilerdir.

Olgusal açıdan yaklaşıldığında ise, hesap verebilirlik bireyin kendi hesap verebilirliğine ilişkin algısıdır. Bireyin kararları ve eylemlerinin bir dış güç odağı tarafından değerlendirileceği, bu değerlendirmeye bağlı olarak ödüllendirileceği veya cezalandırılacağı yönündeki zihniyet olarak kavramlaştırılmaktadır (Hall ve Ferris, 2011). Lerner ve Tetlock (1999) hesap verebilirlik kavramının ne olduğuna yönelik tartışmalarda bazı temel öğelerin hesap verebilirlik kavramının olmazsa olmazları olduğuna vurgu yapmaktadır. Bunlardan ilki muhtemel bir değerlendirmedir. Çalışanın davranışları illaki değerlendirilmek zorunda değildir, değerlendirilme ihtimali dahi yeterlidir. İkincisi, çalışan ast kendinden hesap isteneceğini, bir açıklama bekleneceğine inanmalıdır (Frink, Hall, Perryman, Ranft, Hochwarter, Ferris, ve Royle (2008). Üçüncüsü, değerlendirme sonucuna göre çalışan ast kesinlikle ya ödüllendirilmeli, ya da bir yaptırıma maruz bırakılmalıdır (De Dreu ve Van Knippenberg, 2005). Son olarak, davranış1 gözetleyen güçlü bir dış gözün varlığı da şarttır. Hesap verebilirlik kavramını sorumluluk kavramından ayıran en temel özellik de işte bu gözetleyicinin varlığıdır (Frink ve Klimoski, 1998; Schlenker, Britt, Pennington, Murphy, ve Doherty, 1994).

\section{Bireysel Hesap Verebilirliğin Belirleyicisi Olarak Hesap Verebilirlik Ortamı}

Hall et al. (2007) tarafından kavramlaştırılan ve sonra Frink et al. (2008) tarafından geliştirilen hesap verebilirlik ortamı (accountability environment), bireyin hesaba çekileceği algılamasını, yorumlamasını ve hesap verebilirlik tecrübesini direk olarak etkileyen yakın iş çevresinin özellikleri 
olarak kavramlaştııılmaktadır (Hall et al., 2007). Yapılan çeşitli çalışmalarda da hesap verebilirlik ortamının çalışanın hesap verme algısını şekillendirdiği ortaya konmuştur (Ferris et al., 1995; Frink ve Klimoski, 1998; Hall et al., 2004). Çalışanların yakın iş çevresini ve özelliklerini anlamaya yönelik çalışmalar hesap verebilirlik ortamlarının (i) hesap verebilirliğin kaynağı, (ii) hesap verebilirliğin odağı ve amac1, (iii) hesap verebilirliğin önemi, (iv) hesap verebilirliğin yoğunluğu olmak üzere dört temel boyuta sahip olduğunu belirtmektedir (Hall et al., 2007; Frink et al., 2008).

\section{Hesap Verebilirlik Baskılarının Kaynă̆ı (Accountability Source)}

Hesap verebilirlik kaynağı, çalışma ortamında bireyde oluşan hesaba çekileceği inancının kaynağı olarak kavramlaştırılmaktadır. Frink ve Klimoski (1998), Carnevale (1985) ve Tetlock (1999) çalışma ortamının birçok hesap sorma ve hesap verme ağlariyla dolu olduğunu, bireylerin örgüt içi ve dışında yer alan birçok farklı güç odağından hesap verebilirlik baskısı gördügünü ileri sürmektedir. Denetçiler, müdürler, iş arkadaşları, takım arkadaşları, müşteriler ve diğer paydaşlar çalışanlar üzerinde baskı üreten birimler arasında yer almaktadır. Hatta bireylerin kendileri dahi kendi eylemleri üzerinde açılama ve eylemlerini savunma gerekliliği yönünde bir baskı üretmektedir (Schlenker ve Weigold, 1989).

Bir memurun müşteriye kural dışı davranarak yardımcı olma düşüncesi, kendisini hem ödüllendirme hem de cezalandırma yetkisine sahip olan müdürü tarafından kurum politikalarına uygun davranmadığı gerekçesiyle kendisini cezalandırma ihtimalini düşünerek müşteriye yardımcı olma düşüncesinden vaz geçmektedir (Hall et al., 2007). Bazı durumlarda da bireyin kendisi eylemlerinin haklılığ 1 konusunda kendi üzerinde baskı üretebilmektedir. Hatta kendi değer, inanç ve düşüncelerinden kaynaklanan bu baskılar diğer baskılardan da farklılık gösterebilir. Diğer bir deyişle, farklı kaynaklardan gelen baskılar arasında bir uyumsuzluk ve çatışma hali ortaya çıkabilmektedir. Bu durum, bazı astların diş talep, beklenti, kural, ödül veya cezaların ürettiği hesap verebilirlik bask1sına rağmen kendi benimsediği değerlerin, inançların, ahlak anlayışının gerektirdiği davranışları sergilemesinin en temel nedeni olarak gösterilebilir (Hall et al., 2007). Başka bir çalışmada da Hendricks ve Brickman (1974), performanslarını açıklama veya savunma konusunda bireylerin 
çalışma arkadaşlarından daha çok üstlerine karşı çaba harcadıklarını belirlemiştir.

Çalışan ast üzerinde yaratılan hesap verebilirlik baskısının işlevselliği astın eylemlerine ilişkin hesap verme olayına yüklediği öznel anlama bağlıdır. Bürokratik yaptırımları işe koşan hesap verebilirlik baskıları, eğer ast hesap vermeyi çalışma ortamını düzenleyen kuralların korunması ve sürdürülmesini sağlayan bir mekanizma olarak gördüğünde işlevseldir. Aynı şekilde, ast hesap vermeyi şahsi kimliğiyle veya sosyal imajıla ilgili bir süreç olarak görürse, asta geri bildirim sağlayan, kişiliği oluşturan veya destekleyen dış hesap verebilirlik baskıları daha etkilidir. Dış baskıların sadece algılamayla ilgili olduğu düşünen bir çalışan üzerinde belirli statü sahiplerinin bizzat kendileri veya sağladıkları geri bildirimler kimlik oluşturma veya güçlendirmede daha fazla etki sağlamaktadırlar (Frink et al., 2008).

\section{Hesap Verebilirlik Baskılarının Odă̆ı (Accountability Focus)}

Hesap verebilirlik odağı, çalışma ortamında bireylerin karar verme süreçleri veya alınan kararların sonuçlarına ilişkin, ya da ortaya koydukları eylemleri için ne derece sorumlu tutulduklarıyla ilgilidir. Royle, Hochwarter ve Hall (2008) hesap verebilirlik baskılarının odağını temel olarak (i) sonuç, (ii) süreç ve (iii) çalışanlar olmak üzere üç başlıkta toplamaktadır. Süreç hesap verebilirliğinde ast karar alma sürecinde kullanılan standartlara, ya da kullanılan süreçlere ilişkin sorumlu tutulmaktadır. Sonuç hesap verebilirliğinde ise, neyin nasıl kullanıldığına bakılmaksızın, astların ne kadar kaliteli karar aldıkları, ortaya koydukları ürünlerin çokluğu konusunda sorumlu tutulmaktadır (Hall et al., 2007; Hall, Zinko, Perryman ve Ferris, 2009; Lerner ve Tetlock, 1999; Siegel-Jacobs ve Yates, 1996). Öte taraftan, çalışan odaklı hesap verebilirlikte, bireyler iş yerinde sergilediği davranışlardan veya ürettiği sonuçlardan diğerlerine karşı sorumlu tutulmaktadır (Menon ve Akhilesh, 1994). Yapılan araştırmalarda hesap verebilirlik baskılarının odağı hem bireyden bağımsız nesnel bir ortam olarak, hem de bireyin öznel algılaması ve yorumu olarak ele alınmaktadır (Tetlock, 1985; 1992). 
Yapılan çalışmalar süreç odaklı hesap verebilirliğin daha çok olumlu sonuçlar ürettiği, sonuç odaklı hesap verebilirliğin de daha negatif sonuçlar ürettiği ileri sürmektedir (Lerner ve Tetlock, 1999; Siegel-Jacobs ve Yates, 1996). Maliyetlerin düşürülmesi, verimlilik, etkililik ya da alt-limit değerler gibi sonuçlar üzerine aşırı odaklanma çalışanlar üzerinde haddinden fazla üretilen hesap verebilirlik baskılarının olumsuz sonuçlar üretmesine neden olmaktadır. Bu baskı kaynakların israfına neden olduğu ve çalışanların dürüstlüğünü tehdit ettiği gibi (Adelberg ve Batson, 1978), karar alırken hissedilen stresin artmasına (Janis ve Mann, 1977), alınan kararların da niteliğinin düşmesine (Siegel-Jacobs ve Yates, 1996), örgütsel yaşam için bir felaket olan ahlak dışı ve yasa dışı davranışların da ortaya çıkmasına neden olmaktadır. Hall et.al (2007) sonuçlar üzerine aşırı odaklılığın ortaya koyduğu bu olumsuz davranışlara gerçek olaylarla örneklemektedir. Buna göre, Amerika'da otomobil firmalarının artan emek ve sağlık sigortası maliyetleri düşürme politikası, üretilen malların kalitesinden ödün vermeye, çevreyi koruyan yasalara duyarsız kalmaya ve hatta etik dışı davranışlar göstermeye götürmüştür. Hewlett-Packard'da yönetim kurulunun görüşmelerinin dışarıya sızdırılması konusunda üst düzey yöneticilerin sonradan istifalarına neden olan yasadışı ve etik olmayan tedbir uygulamaları da sonuç başka bir örnektir. Buradan hareketle, sonuçlar üzerine yapılan aşırı vurgu çalışma ortamında 'sonuç için her yolun mubah olduğu' bir anlayışın gelişmesine, ve böyle bir ortamın da hiçbir şeyi umursamayan alternatif uygulamaların ve etik dışı davranışlara çanak tutacağı iddia edilmektedir (Hall et al., 2007).

Frink et al. (2008) alanyazın temelinde yaptıkları inceleme sonucunda süreç odaklılığın daha çok tercih edilmesi gerektiğine vurgu yapmakta, birçok farklı araştırmacı da (Libby, Salterio, ve Webb, 2004; Scholten, van Knippenberg, Nijstad, ve De Dreu, 2007) çok iyi bir şekilde planlanmış süreçlerin zaten arzu edilen sonuçları doğal bir şekilde üreteceğini ileri sürmektedir. Öte taraftan, yapılan farklı çalışmalar, sonuç odaklılığın veya süreç odaklılığın işlevsel olduğu farklı ortamların ve koşulların varlığına da işaret etmektedir. Davis, Mero ve Goodman (2007) iki aşamadan oluşan karmaşık bir karar alma sürecinin ilk aşamasında sonuç hesap verebilirliğinin katılımcıların performansına olumlu katkı yaptığı, süreç hesap verebilirliğinin ise olumlu katkıyı ikinci aşamada gerçekleştirdiğini tespit etmiştir. Benzer şekilde, Langhe, van Osselaer ve Wierenga (2011) 
doğrusal kararların alınması gerektiği durumlarda süreç hesap verebilirliğin, daha karmaşık karar durumlarında ise sonuç hesap verebilirliğinin daha nitelikli kararlar ürettiğini ortaya koymuşlardır.

Süreç ve sonuç hesap verebilirliğinden farklı olarak, çalışan odaklı hesap verebilirlikte odak iş ve görevlerden uzaklaştırılarak insan unsuruna dikkat çekilmektedir. Bu anlamda, çalışanların diğer çalışanların mesleki gelişimlerini sağlaması, astlarına rehberlik yaparak problem çözmelerine yardımcı olması, çalışanların güvenliklerini ve iyi oluşlarına katkı sağlayan kararları tercih etmesi ve bu yönde davranış üretmesi, insanların iyiliğini eşyanın iyiliğinden daha üstün tutmak ve çalışanların kariyer gelişimlerini ve geleceklerini güven altına almak temel sorumlulukları arasinda yer almaktadır (Ivanchevic ve Matteson, 1980; 1988).

\section{Hesap Verebilirlik Baskılarının Yoğunluğu (Accountability Intensity)}

Hesap verebilirliğin yoğunluğu ise, belirli bir örgüt içerisinde çalışanlar üzerinde farklı kaynaklardan farklı konularda gelen baskıların düzeyi olarak kavramlaştırılmaktadır. Başka bir deyişle, hesap verebilirlik yoğunluğu çalışanın hissettiği toplam baskı şiddeti olarak ele alınmaktadır (Hall et al., 2007). Hesap verebilirliğin yoğunluğu çalışanın ne kadar hesap verme çabası içinde olduğu ile doğru orantılıdır. Frink ve Klimoski'nin (1998) belirttiği üzere, iş yerinde bireyler birçok hesap verebilirlik ilişki ağları içerisinde görev yapmaktadır. Çalışanlar her bir hesap verebilirlik talebi için gerekli olan rolü oynamaya, aldığı kararların ve gerçekleştirdiği eylemlerin haklılı̆̆ını üstlerine göstermesi beklenmektedir. Diğer taraftan, güç odaklarının sayısı veya talepleri artıkça çalışanların iş yükleri de artmaktadır.

Yapılan araştırmalar hesap verebilirlik baskılarının çalışanlarda stres ürettiğini ortaya koymaktadır. Çalışanlar üzerinde oluşturulan hesap verebilirlik baskıları çalışanlar arasında iş stresinin artmasına (Hall et al., 2006; Laird, Perryman, Hochwarter, Ferris ve Zinko, 2009), duygusal tükenişe (Hall et al., 2006), ve iş ortamında depresif moda (Lanivich, Brees, Hochwarter ve Ferris, 2010) neden olduğu ortaya konmuştur. Hall et.al (2007) farklı kaynaklardan gelen farklı taleplerin çalışan için yeni bir problem teşkil ettiğini, baskı kaynakları ve beklentilerin çeşitliliği arttıkça çalı- 
şanlarda stresin de artacağını, sorumluluklarını sürekli olarak dengelemek zorunda olduklarını belirtmektedir. Bazen çalışan üzerinde farklı güç odaklarından gelen hesap verebilirlik baskıları bağımsız olarak çalışan üzerinde yoğunlaşırken, bazen de bu baskılar birbirleriyle çelişir veya çatışır halde yoğunlaşmaktadır. Örneğin, çalışan müşterisine en kaliteli ürünü veya hizmeti üretmekten sorumlu iken, üst yönetimden gelen maliyetleri kısma emri birey üzerinde diğeriyle çelişen yeni bir sorumluluk yükleyebilir. Bu durum çalışanlar üzerinde stres üreten bir durumdur ve çalışanlar farklı kaynaklara sahip hesap verebilirlik baskılarının ürettiği yoğunluğu kendine göre önceliklendirme, ortaya çıkan stresi ise azaltmanın yollarını aramak zorunda kalmaktadır.

Çalışma ortamlarında her çalışan farklı düzeyde hesap verebilirlik baskılarına maruz kalmaktadır. Baskılar ise her zaman olumsuz sonuçlar üretmemektedir. Ganster ve Schaubroeck (1991) hissedilen yüksek düzey stresin genellikle olumsuz sonuçlar ürettiğini, buna karşın orta ve düşük düzey stresin ise çalışanlarda işe karşı bir merak ve itici bir güç ürettiğini ortaya koymaktadır. Buradan hareketle, hesap verebilirlik baskıları yüksek düzeyde stres ürettiğinde işte zorlanma gibi olumsuz sonuçlar ürettiği gibi, orta ve düşük düzey stresin de örgüt için faydalı olan iş doyumu gibi olumlu sonuçlar da üretmektedir (Laird et al., 2009). Birçok farklı kaynaktan veya farklı ürün veya hizmet için çalışanlar üzerinde üretilen baskıların ortaya çıkardığı stresin azaltılması veya olumsuz etkilerinin ortadan kaldırılması büyük önem arz etmektedir. Ganster (1989) ile Ganster ve Schaubroeck (1991) yaptıkları çalışmalarda çalışanlara özgürce düşünebilme ve davranabilme, ayn zamanda hesap verebilirlik taleplerini daha dingin bir şekilde algılama ve anlama fırsatı verildiğinde çalışanların hesap verebilirlik talep ve isteklerini bir tehdit olarak algılamaktan vazgeçeceğini, dolayısıyla hissedilen stresin de azalacağını göstermişlerdir. Bu anlayıştan hareketle, çalışanlara sorumluluklarına ilişkin standartların belirlenmesi ve performans değerlendirmesinin nasıl yapılacağı konusunda gerekli yetkilere, bununla beraber sorumluluklarını yerine getirme sürecinde gerekli görülen kaynaklara ve becerilere sahip olmaları hesap verebilirlik baskılarına ilişkin algıyı hafifletecek ve yumuşatacaktır (Hall et al., 2007). 


\section{Sorumluluklarn Ehemmiyeti: (Accountability saliance)}

Asta yönelik hesap verebilirlik taleplerinin önemi iş yerinde sorumlu tutulan görev veya sonuçların büyüklüğü, önemi, ciddiyeti kadardır (Hall et al., 2007). Çevrelerinden onlarca uyaran alan bireyler ve örgütler, sadece kendilerince en önemli kabul edilen uyaranlara dikkat etmekte, dolayısıyla sadece bunlar tutum ve davranışı şekillendirmektedir (Du Toit, 2003). Kararlarının veya eylemlerinin ait oldukları grup veya örgütün başarısı için büyük önem taşıdığına inanırlarsa, bireylerin daha yüksek derecede bilişsel çaba gösterecekleri ve daha dikkatli davranacakları tahmin edilmektedir (Smith, Terry, ve Hogg, 2007). Hall et al. (2007) bu durumu şu şekilde açıklamaktadır: Bir hastanede görev yapan doktor ve hemşireler evrak memurlarına kıyasla daha çok hesap vermeye hazırdır. Çünkü yaptıkları hastanın direk sağlığıyla ilgilidir ve herhangi bir hata hastanın ölümüne kadar giden önemli sonuçlar üretmeye muktedirdir.

Hesap verebilirlik baskısı altında yapılan işin veya ortaya çıkacak sonucun önemi alanyazındaki çeşitli çalışmalarda da ortaya konmuştur. Staw ve Boettger (1990) yöneticinin hesap verebilirlik baskısı altındayken yanlış davranışın veya sürecin düzeltilmesi amaçlı alternatif olarak planlanan eylemler önemsendiği ve benimsendiği takdirde olumlu sonuç ürettiğini tespit etmiştir. Benzer şekilde, Kramer, Pommerenke ve Newton (1993) deneysel çalışmalarında bireyler arası hesap verebilirliğin ve sosyal kimliğe yapılan güçlü vurgunun bireylerin adalet, doyum ve iş birliği duygularını da artırdığını tespit etmiştir. Roberts, Stout ve Halpern (1994) göreve ilişkin teknik zorluk, karmaşıklık ve yıkıcı sonuçların yanı sıra duruma verilen önem ve hesap verebilirlik bilinci gibi bilişsel faktörlerin de karar vermeyi şekillendirdiğini belirtmiştir.

\section{Sonuç ve Tartışma}

Eğitim sisteminin en temel unsurlarından olan okulların açık ve sosyal bir sistem olduğu göz önüne alındığında, dış unsurlardan ve insan faktöründen etkilenmemesi imkansızdır. Sağladıkları kıt kaynaklarla eğitim öğretim süreçlerini en etkili ve verimli bir şekilde gerçekleştirmeye çalışan okulların ve öğretmenlerin aldıkları kararlar, uygulamaları ve ürettikleri sonuçlar okul içi ve dışı çeşitli güçler tarafından gözlenmekte, izlenmekte 
ve değerlendirilmektedir. Ancak bu şekilde, doğru geri bildirimlerle işleyişi ve sonuçları düzeltme ve geliştirme imkanı bulunabilmektedir.

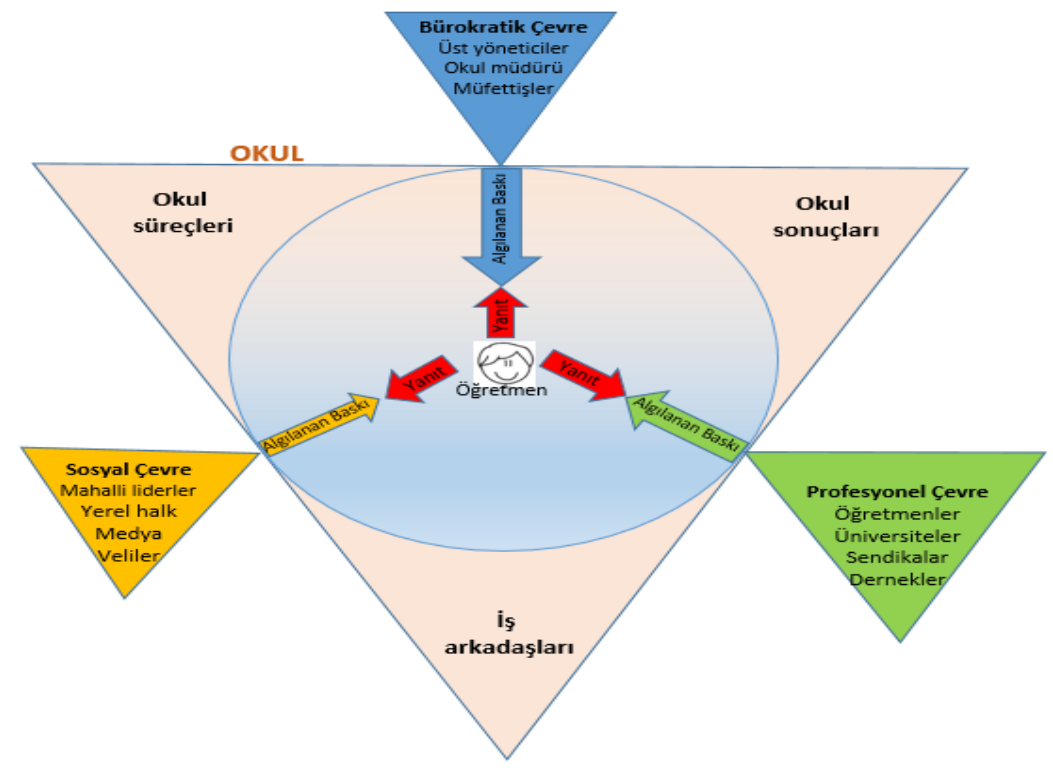

Şekil 1. Öğretmenlerin Hesap Verebilirlik Çevreleri (Beklentiler, Odak, Önem ve Yoğunluk)

Yapılan tarama ve inceleme sonucu ortaya konulan ve Şekil 1'de özetlenen dört boyutlu teorik hesap verebilirlik ortamları modeli öğretim süreçleri ve sonuçlarının kontrolü açısından önemli bir kılavuz olma özelliğine sahiptir. Örgütsel davranış ve sosyal psikoloji disiplinleri üzerinden çalışanların hesap verebilirliği üzerinde yapılan çalışmalar okullardaki hesap verebilirlik ortamları ve bireylerin hesap verebilirliği üzerine önemli bir bakış açısı kazandırma, Türkiye' deki tartışmaları ve araştırmaları yeni bir boyuta taşıma potansiyeli barındırmaktadır. Konu sosyal etkileşimi yüksek olan okullarda görev yapan öğretmenler bağlamında ele alındığında, öğretmenlerin içsel hesap verebilirlik inançlarının güçlendirilmesi sadece görev motivasyonlarının ve kapasitelerinin artmasına değil, aynı zamanda onların iyi oluşlarının artırılmasında da büyük bir potansiyel etkiye sahiptir.

Unutmayalım ki, eğitim sistemi ve okullar iyi bir vatandaş, iyi bir insan ve iyi bir meslek sahibi bireyler yetiştirmeyi temel amaç edinmiş ve bunun 
için işleyen kurumlardır. Dolayısıyla, tüm kaynak ve unsurların bu amaçların gerçekleştirilmesi için işe koşulması, yönetici ve öğretmenlerin okulların bu amaçları başarmasına yöneltilmesi bir zorunluluktur. Bu ise yapılanların okulların amaçlarına hizmet edip etmediğini, işlerin planlandığı gibi yürüyüp yürümediğini sürekli ve doğru bir şekilde kontrol etmeyi gerekli kılmaktadır. Sadece bürokratik mekanizmalarla değil, hem piyasa hem de profesyonel mekanizmalarla öğretmen davranışları belirli bir düzeyde kontrol altında tutulmalıdır. Bu kapsamda, Türkiye'de öncelikle eğitim süreçlerini ve sonuçlarını düzenleyecek uygun ve işlevsel bürokratik kontrol mekanizmaları gözden geçirilmeli, yeniden işlevsel hale getirilmelidir. Çünkü okulların ve öğretmenlerin görev içerikleri bellidir, ve görevlerini yerine getirirken bağımsız davranmalarına imkan sağlanmıştır. Öğretmenler, ve bir bütün olarak okullar, eğitim amaçlarına ulaşmak için sınıfta veya okulda yapılması gerekeni kendileri kurgulayıp uygulama yetkisine sahiptirler. İstenilen amaçlara ulaşmak için daha işin başında iş girdilerine, süreçlerine ve sonuçlarına ilişkin standartların belirlenmesi ögrretmenler ve okul müdürleri üzerinde hesap verebilirlik baskisının oluşturulmasında büyük önem taşımaktadır. Bunu için öncelikle, (i) öğretmen ve yöneticilerin yeterlilikleri, seçimi, mesleki gelişimleri, mesleki etik ve davranışlara ilişkin kendilerinden neler beklendiğini açı ve net olarak yazılı bir şekilde ortaya koyan kuralların veya ilkelerin geliştirilmesi ve uygulamaya konulmasının yanı sıra, bunlara göre izlenilmesi ve değerlendirilmesi önemlidir. Öğretmenlerin, okul müdürlerinin ve üst yönetim birimlerinin üzerinde uzlaştığı ve başarılması için çaba gösterilmesi gereken performans standartlarının belirlenmesi gerekmektedir. Performans standartları ise, eğitim öğretim işinin gereklerine bağlı olarak finansal, personel, mevzuat, sosyal etkinlikler ve/veya özellikle öğretime ilişkin faaliyetleri kapsayabilir. Burada dikkat edilecek husus, standartların ölçülebilir, ulaşılabilir ve birbirleriyle uyumlu olmalarının sağlanmasıdır. Öğretmenler veya okullar üzerinde sadece birbirleriyle çelişen veya çatışan beklentilerden değil, aşırı iş yükü oluşturan standartlardan da vazgeçilmelidir. İkincisi, (ii) formal geri bildirim mekanizmalarına da işlerlik kazandırılmalıdır. Okul ve sistem düzeyinde yönetim bilgi sistemleri ile eğitim ve öğretime ilişkin kilit öneme sahip olan veriler zamanında gözlenmeli, ölçülmeli ve raporlanmalıdır. Okul müdürleri, üst yöneticiler veya müfettişler yazılı ve sözlü raporların yanı sıra sahaya inmeli, sınıfta 
veya okulun farklı bölümlerinde neler olup bittiğini birinci elden deneyimlemeli, elde ettiği subjektif ve objektif performans verilerini zamanında, dikkatli bir şekilde ve sürekli olarak değerlendirmeli, aksayan yönleri tespit ederek bunların üzerine gitmelidir. Veriler sadece öğretmenlerden, okul içi kalite geliştirme ekiplerinden veya bireysel gözlemlerden değil, süreçlere dahil olan veya son kullanıcı olan öğrenci ve velilerden de sağlanmalıdır. Hatta, diğer okul müdürlerinin veya bağımsız dış denetim kurumlarının denetimleri talep edilmeli, onların standartları ve bakış açılarına göre öğretime ilişkin girdiler, süreçler ve öğretim sonuçlarına ilişkin dış geribildirim sağlanmalıdır. Üçüncü olarak, (iii) okul ve sistem düzeyinde gerçekleştirilen performans değerlendirme sürecinin sonucuna göre doğru işlerin desteklenmesine devam edilmeli, yanlış süreçlerin ise düzeltilmesi sağlanmalıdır. Bunun için, yeni stratejiler, yeni süreçler veyeni yöntemler işe koşulabileceği gibi, gerektiğinde ceza ve yaptırımlar da uygulanabilir. $\mathrm{Bu}$ anlamda bürokratik kontrol mekanizmaları kullanılarak öğretmenler ve okul yöneticileri üzerinde etkin hesap verebilirlik baskıları üretilmesi olanaklıdır.

Eğitimde nelerin başarılacağı net bir şekilde ortaya konmasına rağmen bunlara nasıl ulaşılacağı net değildir. Çünkü eğitim ve öğretimin en iyi yolu yoktur, ve öğretmenler yeterli kapasite ve motivasyona sahip olduklarında her zaman daha iyi bir yol üreteceklerdir. Öğretim süreçleri bilgi temelli olduğundan uzmanlık da istemektedir. Bu anlamda öğretim işinin standartlaştırılması ve yakından kontrolü her zaman imkan dahilinde değildir. Ayrıca, öğretmenler öğretim faaliyetlerinde alınacak kararlara daha çok katılmak, takım ruhu içerisinde hareket etmek, daha zorlayıcı görevleri üstlenmek ve problem çözme eğilimindedir. Bu nedenlerle öğretmenlerin işlerinde güçlendirilmeleri daha çok tercih edilen bir politika haline dönüşmüştür. Bu ise bürokratik kontrol yerine daha çok profesyonel ve kültürel bir kontrolü gerekli kılmaktadır. Bu nedenle, formal kontrol mekanizmaları yanı sıra, informal kontrol mekanizmalarına da işlerlik kazandırılması bir zorunluluktur. Bunun için öncelikle, (i) üst yönetim birimleri doğru davranışları cesaretlendiren ve yanlış olanlardan caydırıcı bir kontrol söylemi ve kültürü geliştirmeli, kontrole olan ihtiyacı ön plana çıkarmalı, kontrolün gerekli ve vazgeçilmez bir süreç olduğu anlayışını hem sözleriyle hem de eylemleriyle herkese göstermelidir. Bu anlayış 
özellikle okullarda geliştirilmeli ve pekiştirilmelidir. İnformal geri bildirimlere kıymet gösterilmeli, okul geliştirme süreçlerinde informal bilgilerin üretilmesi ve değerlendirilmesi teşvik edilmelidir. Bu anlamda, okul yöneticileri için her bir öğretmen bir kalite bekçisi olarak işlev görmeli, eğitim ve öğretim süreçlerinde gördüğü aksaklıkları yönetime bildirmesi yönünde teşvik edilmeli, çözüm görüşlerine de kıymet gösterilmelidir. $\mathrm{Bu}$, öğretmenlerin eylemlerinin sorumluluğunu almaya teşvik edecektir. Öğretmenlerin okulun vizyonunu, değerlerini, beklentilerini ve amaçlarını paylaşmasını ve buna uygun bir davranış sergilemesini sağlayacaktır. Başka bir deyişle, etkili bir kontrol kültürü okulları veya öğretmenleri aynı rüyayı görmeye, ortak amaç ve değerlere sahip olmaya, ve birbirlerine güven duymaya sevkedecektir. Tüm bunlar içinse, etkili bir liderliğe, güçlü bir okul kültürüne, mesleki etik ilkelere ve uyumlu bir takım çalışmasına gerek duyulmaktadır.

Öte taraftan, çalışanların yaptıkları işin ehemmiyetine ilişkin algıları onların hesap verebilirliklerini belirliyorsa, fiyatlandırma mekanizmaları bu anlamda öğretmenlerin hesap verebilirliklerini artırma potansiyeline sahiptir. Öğretmenlerin sundukları hizmet ne kadar kıymetli ise, o nispette ona verilen ek ücret veya terfi imkanı onların hesap vermeye yönelik inanç düzeylerini de yükseltecektir. Unutulmamalı ki, kontrol anlayışından taviz vermek okulların misyonlarına hizmet eden eğitim öğretim süreçlerinde yozlaşmaya, istenmeyen veli, öğrenci, öğretmen ve yönetici davranışlarının filizlenmesine imkan sağlayacak, bu da okulları hedeflerinden uzaklaştıracak, etkisizliğe ve verimsizliğe itecektir. Bu ise toplumsal bir felaketin habercisidir.

Araştırmacılar açısından bakıldığında, öğretmenlerin hesap verebilirlik çevresi Türkiye' de keşfedilmeyi ve anlaşılmayı bekleyen bakir bir konu olarak ortaya çıkmaktadır. Bu anlamda, farklı kanallardan gelen ve öğretmenleri hedefleyen hesap verebilirlik baskılarının Türkiye'de hangi konulara yöneldiği, hissedilen baskıların ne düzeyde olduğu, öğretmenlerin hesap verebilirlik deneyimlerinin neler olduğu, hissedilen bürokrasi, piyasa ve profesyonel performans baskılarının kurgulandığı gibi öğretmenlerin tutum, düşünce ve performanslarına etki edip etmediğine ilişkin nitel ve nicel emprik kanıtların üretilmesi gerekmektedir. 


\title{
EXTENDED ABSTRACT
}

\section{Teachers' Accountability Environments: Implications for Turkish Schools}

\author{
Coşkun Erdağ
}

Aksaray University

Accountability is considered as one of the main elements in the establishment and maintenance of order in organizational life as in the social life by controlling not only the coordination of actions but also ensuring the control of the negative-jams and results in the organization, thereby increasing productivity, effectiveness and also ensuring justice (Enzele and Anderson, 1993; Frink and Klimoski, 1998; Hall et al. 2003; Hall, Ferris, Bowen \& Fitzgibbons, 2007; Monks \& Minow, 1991; Tetlock, 1985; 1992; Yarnold et al., 1988). This also applies to ensuring that teachers who work in schools with a social and open system avoid ethical and illegal behaviour and act in accordance with the expectations. In this respect, strengthening the accountability beliefs of teachers in school life and finding ways to achieve efficiency, effectiveness and justice are of great importance. The literature states that accountability environments in which employees are at work reinforce their own accountability beliefs (Ferris et al., 1995; Frink and Klimoski, 1998; Hall et al.,2004; Hall et al., 2007), there is however hardly any work in Turkey on this issue, the discussions available is rather focused on who should be accountable to whom for what, and how in an organizational life, and determination of the institutional and individual factors that impact account-giving, and the accountability practices at public organizations and schools (Bülbül, 2011; Çiçekli, 2016; Erdağ, 2017; Erdağ and Karadă̆, 2017; Erkoşar, 2013; Kantos, 2010; Küçükaycan, 2018; Özen, 2011; Özcan, 2011; Salduz, 2013; Türkoğlu, 2015; Yıldırım and Yenipınar, 2019). From this point of view, this study aims to create a theoretical framework based on national and international literature on how school life shapes the accountability beliefs of employees. Therefore, the research questions are: (i) what are the basic characteristics of a working environment that make employees accountable; (ii) how should a working 
school environment with these characteristics be structured? To this end, literature review was performed in national and international databases (ISIS web of science, Eric, PsycINFO, TR Index, YÖK thesis) through key words search for "accountability", "hesap verebilirlik [accountability in Turkish]", the content obtained was analyzed and holistically evaluated.

\section{Accountability and Personal Acountability}

The literature reveals that accountability, which is used in different meanings such as accountancy, description, explanation, advocacy, justification and responsibility in western languages, is also conceptualized as a glue that keeps social systems together. Tetlock (1992) argues that for a healthy social system, however, individuals should be possible to question the rightness of their decisions and actions, and Frink and Klimoski (2004) assert that it is a process of account-giving built on two basic elements giving, (i) bilateral relations and (ii) evaluation and feedback. The principal, the legitimate authority and the powerful side at the accountability relationship, monitors and evaluates the decisions and actions of the agent (subordinate) for a specific reason (Adelberg and Batson, 1978; Cummings and Anton, 1990). In some accountability relationships, the individual himself is both the account-holder and account-giver (Schlenker and Weigold, 1989).

One of the two main approaches to explaining individual accountability is to conceptualize it as an effect produced by external circumstances, and the second is to consider it as an inner world, mood or mindset (Frink and Klimoski, 1998; Hall, Frink and Buckley, 2017). In terms of external environment and conditions, accountability is more focused on how the environmental forces influence and shape individual feelings of accountgiving (Cummings and Anton, 1990; Fandt and Ferris, 1990; Mero and Motowidlo, 1995). This involves the study of the individual's actions by a legitimate external force and the process of reward or sanction (Frink and Ferris, 1998; Hall and Ferris, 2011). From phenomenological perspective, accountability is the individual's own perception of his account-giving. It is conceptualized as the mindset in which decisions and actions of the individual are believed to be evaluated, rewarded or punished by an external power depending on this value-assessment (Hall and Ferris, 2011). For 
personal accountability, it is required to have an external eye that monitor individual deeds and decisions (Frink and Klimoski, 1998; Schlenker et al., 1994), an assessment of individual or even its possibility (Lerner and Tetlock, 1999), the individual belief that s/he will be asked for a self-account (Frink et al., 2008), a knowledge that s/he will either be rewarded or will be subject to a sanction (De Dreu \& Van Knippenberg, 2005).

\section{Accountability Environment As An Antecedent of Personal Accounta- bility}

Accountability environment, first conceptualized by Hall et al. (2007) and then enriched by Frink et al. (2008), are defined as environmental characteristics that directly affect the individual perception, interpretation and experience of accountability (Hall, Bowen, Ferris, Royle and Fitzgibbonds, 2007) and built on four pillars: (i) the source, (ii) the focus and purpose, (iii) the intensity of accountability pressures, and (iv) accountability salience (Frink et al. 2008; Hall et al. 2007).

Sources of accountability pressures: The accountability source is conceptualized as the source of the belief that an individual will be taken into account in the working environment. Frink and Klimoski (1998), Carnevale (1985) and Tetlock (1999) assert that the working environment is full of accountability relations, and that individuals have access to a variety of different loci of power within and outside the organization. Auditors, managers, co-workers, teammates, customers and other stakeholders are among the units that produce pressure on employees. Even the individual himself produces a pressure on his self for the need to defend their actions and statements on their own actions (Schlenker and Weigold, 1989). These pressures, which sometimes originate from their own values, beliefs and thoughts, may differ from pressures of others.

Focus of accountability pressures: Roy, Hochwarter and Hall (2008) asserts that accountability pressures mainly focus on the (i) results, (ii) processes and (iii) employees. In process accountability, the agent is accountable for the standarts in decision-making process or work processes. In 
outcome accountability, the agent is responsible for how much quality decisions are made and for the abundance of products, regardless of what is used in the processes by the subordinates (Hall et al., 2009; Hall et al., 2007; Lerner and Tetlock, 1999; Siegel-Jacobs and Yates, 1996). On the other hand, in employee-oriented accountability, individuals are held accountable to others for their behaviours in the workplace, or for their results (Menon and Akhilesh, 1994). Many studies reveal that outcome accountability has negative impacts (Lerner and Tetlock, 1999; Siegel-Jacobs and Yates, 1996), and it is claimed that an understanding in the working environment that every way to achieve results is legitimate will rise, and that such an environment is supposed to be a nest for alternative practices and unethical behaviour that do not care about anything (Hall et al., 2007). A review by Frink et al. (2008) advises the preference of process accountability and many other studies support this advice (Libby et al., 2004; Scholten et al., 2007), and argue that well-planned processes will already produce desirable results in a natural way. In employee accountability, it is expected that employees will help other employees to solve organizational problems by guiding their subordinates, prefer to make decisions that contribute to their safety and well-being, and that they will behave in this direction, that people are better off than the good ones and that employees are expected to secure their career development (Ivanchevic and Matteson, 1980; 1988).

Intensity of accountability pressures: The intensity of accountability is considered as the total pressure felt by the employee of accountability from different sources and with different focuses (Hall et al., 2007). It is expected that the role-making is required for each accountability relation, and that the agent should justify their decisions and deeds (Frink and Klimoski, 1998). As the number of principals and their demands increase, the workload of the agent also increases. Hall et al. (2007) indicate that different demands from different sources pose a new problem for the agent and that stress will increase as the variety of accountability pressure sources and expectations increase, and that they have the right to balance their responsibilities continuously. Sometimes accountability pressures from different sources conflict with each other. On the other hand, pressures do not always produce negative results. Ganster and Schaubroeck 
(1991) revealed that high-level agent stress often produces negative results, whereas moderate and low-level stress produces a curiosity and impulsive force for agents.

Accountability salience: The importance of the accountability demands for the agent is as much as the magnitude, importance and seriousness of the tasks or their results that the agent is held responsible at the workplace (Hall et al., 2007). Individuals who receive tens of stimuli from their environment pay attention only to stimuli which are considered to be the most important, and therefore only these are shaping gent's attitudes and behaviour (Du Toit, 2003). If employees believe that their decisions or actions are of great importance to the success of the group or organization to which they belong, it is estimated that individuals will make a higher cognitive effort and act more carefully (Smith et al., 2007). For example, Staw and Boettger (1990) found in their studies that positive organization outcomes emerge when the manager under the pressure of accountability gives a high value an alternative action planned to correct the wrong behavior or the process.

\section{Conclusion}

The literature review results in a four-dimensional theoretical model of teacher accountability environment, as guided by Hall et al. (2007) and Frink et al. (2008), and are summarized in Figure 1.

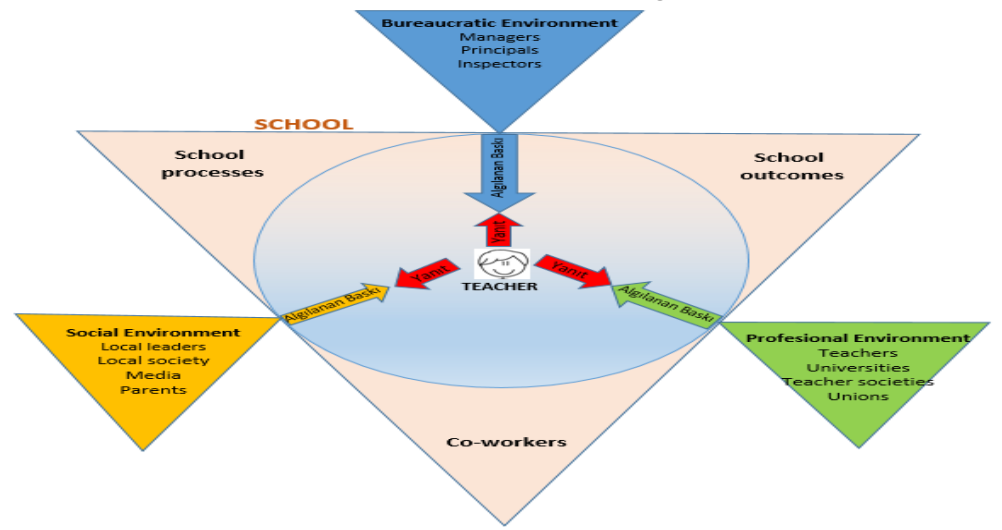

Figure1: Teacher Accountability Environment: Expectations, Focus, Salience, and Intensity 
It bears a great potential to guide the teacher accountability practices in school settings to increase efficiency, effectiveness and justice in teaching processes and outcomes.

Establishment and operation of formal control systems: In order to ensure the desired quality increase in the Turkish education system, professional standards should be first determined in a clear way, which benchmark the competencies, selection processes, professional development, professional ethics and behaviours of teachers and managers directly or indirectly related to the task of teaching. In addition, teacher performance standards which are measurable, accessible, compatible with each other, and do not have excessive workload for the agent, should be set that include finance, human resources, legislations, social activities and particular educational activities. Moreover, teacher candidates and teachers in charge should be monitored and evaluated according to the specified professional and performance standards. Through management information systems, both at school and system level, subjective and objective data that are key to education and training should be produced from all educational stakeholders based on observations and measurements, and then carefully and continuously evaluated. Based on the performance evalutions, good teacher practices should be rewarded and shared among the colleques, and for unsufficient performances teachers and principals shoud be both financially and technically assisted for their improvement in motivation and capacity.

Although goals in education are clearly set, it is not clear how to reach them. Since teaching is more knowledge-based, a better way of teaching is always possible when teachers have sufficient capacity and motivation. In this sense, standardization and close control of teaching is not always possible. In addition, teachers tend to more participate in decision-making related to teaching activities, act in a team spirit, take on more challenging tasks and solve problems. For these reasons, the empowerment of teachers in their jobs has become a more preferred policy. This requires more professional and cultural control rather than bureaucratic one. Therefore, in addition to formal control mechanisms, it is a necessity to provide func- 
tionality to informal control mechanisms. For this purpose, (i) upper management units should develop a discourse and culture of control that encourages correct behaviour and deterrence from wrong ones, bring control to the fore, show everyone that control is a necessary and indispensable process by both words and actions. Informal feedback should be appreciated in schools, and informal information should be encouraged to be produced and evaluated in school development processes. In this sense, each teacher should act as a quality guard for school administrators, be encouraged to inform management about the deficiencies they see in their education and training processes, and be valued for their views of solution. In this sense, effective control culture make teachers envision the same dream, have common goals and values, and trust each other. For all of this, effective leadership, strong school culture, professional ethical principles and consistent teamwork are required.

As for the researchers, the teachers' accountability environment is emerging as a new topic to be discovered and understood in Turkey. In this sense, qualitative and quantitative empirical evidence should be produced on which accountability pressures focus on what, on the level of the pressures felt, the experiences of the accountability of teachers, and whether the accountability pressures of bureaucracy, market and the profession influence or not teachers' attitudes, opinions and performances at work.

\section{Kaynakça / References}

Adelberg, S., ve Batson, C. D. (1978). Accountability and helping: When needs exceed resources. Journal of Personality and Social Psychology, 36(4), 343-350.

Aucoin, P. ve Jarvis, M. D. (2005). Modernizing government: A framework for reform. Ottawa: Canada School of Public Service.

Balcı, A. (2003). Kamu yönetiminde hesap verebilirlik anlayışı, A. Balcı, A. Nohutçu, N.K. Öztürk ve B. Coşkun (Ed.), Kamu Yönetiminde Çă̆daş Yaklaşımlar. Ankara: Seçkin Yayıncılık.

Bovens, M. (2007). Analysing and assessing accountability: A conceptual framework. European Law Journal, 13(4), 447-468.

Bovens, M. (2010). Two concepts of accountability: Accountability as a virtue and as a mechanism. West European Politics, 33(5), 946-967. 
Bülbül, M. (2011). Türk milli eğitim sisteminde hesap verebilirlik. Doktora tezi, Gazi Üniversitesi Eğitim Bilimleri Enstitüsü, Ankara.

Carnevale, P. (1985). Accountability of group representatives and intergroup relations. In E. J. Lawler (Ed.), Advances in group processes (2, p. 227-248). Greenwich, CT: JAI Press.

Çiçekli, A. (2016). Kamu yönetiminde hesap verebilirlik ve BIMER'in hesap verebilir yönetime etkisi: Van sağlık hizmetleri örneği. Yüksek lisans tezi, Yüzüncü Yıl Üniversitesi, Van.

Cummings, L. L., ve Anton, R. J. (1990). The logical and appreciative dimensions of accountability. In S. Srivastava, D. Cooperrider, \& Associates (Eds.), Appreciative management and leadership (p. 257-286). San Francisco, CA: Jossey-Bass.

Davis, W. D., Mero, N., ve Goodman, J. A. (2007). The interactive effects of goal orientation and accountability on task performance. Human Performance, 20, 1-21.

Day, P. ve Klein, R. (1987). Accountabilities: Five public services. London: Tavistock.

De Dreu, C. K., ve van Knippenberg, D. (2005). The possessive self as a barrier to conflict resolution: Effects of mere ownership, process accountability, and self-concept clarity on competitive cognitions and behavior. Journal of Personality and Social Psychology, 89, 345357.

Du Toit, A. (2003). Knowledge: A sense making process shared through narrative. Journal of Knowledge Management, 7, 27-37.

Dubnick, M. (2002). Seeking salvation for accountability. Annual Meeting of the American Political Science Association, Boston, 01.01.2019 tarihinde http://mjdubnick.dubnick.net/papers/2002/salv2002.pdf adresinden erişildi.

Enzele, M. E., ve Anderson, S. C. (1993). Surveillant intentions and intrinsic motivation. Journal of Personality and Social Psychology, 64(2), 257-266.

Erdağ, C. (2017). Accountability at schools: A study of path analysis. Educational Sciences: Theory and Practice, 17 (4), 1405-1432.

Erdağ, C. ve Karadağ, E. (2017). Öğretmenler ve okul müdürleri perspektifinden okul hesap verebilirliği politikaları. OPUS Uluslararası Toplum Araştırmaları Dergisi, 7 (13), 459-496. 
Erdağ, C. ve Karadağ, E. (2018). Exploration of Possible Individual and Institutional Effects on School Accountability Pressures and Teacher Responses. Educational Administration: Theory and Practice, 24 (1), 93-142.

Erkoşar, N. (2013). Belediyelerde iyi yönetişim açısından hesap verebilirlik: Küçükçekmece Belediyesi, Yüksek lisans tezi, Fatih Üniversitesi, İstanbul.

Fandt, P. M. ve Ferris, G. R. (1990). The management of information and impressions: When employees behave opportunistically. Organizational Behavior and Human Decision Processes, 45, 140-158.

Ferris, G. R., Mitchell, T. R., Canavan, P. J., Frink, D. D. ve Hopper, H. (1995). Accountability in human resource systems. In G. R. Ferris S. D. Rosen ve D. T. Barnum (Eds.), Handbook Of Human Resource Management (pp. 175-196). Oxford, UK: Blackwell Publishers.

Frink, D. D. ve Ferris, G. R. (1998). Accountability, impression management, and goal setting in the performance evaluation process. $\mathrm{Hu}$ man Relations, 51, 1259-1283.

Frink, D. D. ve Klimoski, R. J. (1998). Toward a theory of accountability in organizations and human resource management. In G. R. Ferris (Ed.), Research In Personnel And Human Resources Management, Vol.16. (p. 1-51). Stamford, CT: JAI Press.

Frink, D. D. ve Klimoski, R. J. (2004), Advancing accountability theory and practice: Introduction to the human resource management review special addition, Human Resource Management Review, 14, 1-17.

Frink, D. D., Hall, A. T., Perryman, A. A., Ranft, A. L., Hochwarter, W. A., Ferris, G. R. ve Royle, M. T. (2008). A meso-level theory of accountability in organizations. In J. J. Martocchio (Ed.), Research In Personnel And Human Resources Management (27, p. 177-245). Bingley, UK: Emerald Group Publishing Ltd.

Ganster, D. C. (1989). Worker control and well being: A review of research in the workplace. In S. L. Sauter ve C. L. Cooper (Eds.), Job Control And Worker Health (pp. 3-23). London: John Wiley \& Sons.

Ganster, D. C., ve Schaubroeck, J. (1991). Work stress and employee health. Journal of Management, 17(2), 235-271. 
Hall, A. T., ve Ferris, G. R. (2011). Accountability and extra-role behavior. Employee Responsibilities and Rights Journal, 23, 131-144. doi:10.1007/s10672-010-9148-9.

Hall, A. T., Blass, F. R., Ferris, G. R., ve Massengale, R. (2004). Leader reputation and accountability: Implications for dysfunctional leader behavior. Leadership Quarterly, 15(4), 515-536.

Hall, A. T., Ferris, G. R., Bowen, M. G., ve Fitzgibbons, D. E. (2007). Accountability as a perceptual lens for framing management education. Business Horizons, 50, 405-413.

Hall, A. T., Royle, M. T., Brymer, R. A., Perrewé, P. L., Ferris, G. R., ve Hochwarter, W. A. (2006). "Relationships between felt accountability as a stressor and strain reactions: The neutralizing role of autonomy across two studies." Journal of Occupational Health Psycho$\log y, 11,87-99$.

Hall, A. T., Zinko, R., Perryman, A. A., ve Ferris, G. R. (2009). Organizational Citizenship Behavior and Reputation: Mediators in the Relationships Between Accountability and Job Performance and Satisfaction. Journal of Leadership \& Organizational Studies, 15(4), 381392. https://doi.org/10.1177/1548051809331504

Hall, A.T., Frink, D.D., Ferris, G.R., ve Hochwarter, W.A., Kacmar, C.J., \& Bowen, M.G. (2003). Accountability in human resources management. In C.A. Schriesheim \& L. Neider (Eds.), New directions in human resource management: 29-63 (A volume in the Research in Management series). Greenwich, CT: Information Age Publishing.

Hall, A. T., Frink, Dwight, D., ve Buckley, M. R. (2017). An accountability account: A review and synthesis of the theoretical and emprical research on felt accountability. Journal of Organizational Behaviour, 38, 204-224.

Hendricks, M., ve Brickman, P. (1974). Effects of status and knowledgeability of audience on self-presentation. Sociometry, 37, 440-449.

Ivancevich, J., ve Matteson, M. (1980). stress and work: a managerial perspective. Glenview, IL: Scott, Foresman.

Ivancevich, J. ve Matteson, M. (1988). Stress diagnostic survey (SDS) conmments and psychometric properties of a multidimensional self report inventory. Houston: FD Associates.

Janis, I. L., ve Mann, L. (1977). Decision making. New York: Free Press 
Jordan, S. R. (2011). Accountability in two non-western contexts. In Melvin J. Dubnick ve H. George Frederickson (Eds.), Accountable Governance: Problems And Promises (p. 241-254), Armonk, NY: M.E. Sharpe.

Kantos, Z. (2010). İlköğretim okulu yönetici ve öğretmenlerinin görüşlerine göre kamu ve özel ilköğretim okullarn için bir hesap verebilirlik modeli. Yayınlanmamış doktora tezi, Ankara Üniversitesi, Ankara.

Koppell, J. G. S. (2011). Accountability for Global Governance Organizations. In Melvin J. Dubnick ve H. George Frederickson (Eds.), Accountable governance: Problems and promises (p. 55-77), Armonk, NY: M.E. Sharpe.

Kramer, R. M., Pommerenke, P., ve Newton, E. (1993). The social context of negotiation: Effects of social identity and interpersonal accountability on negotiator decision making. Journal of Conflict Resolution, 37(4), 633-654. http://dx.doi.org/10.1177/0022002793037004003

Kuchapski, R. P. (2001). Reconceptualizing accountability for education. Doctoral dissertation, Retrieved from ProQuest Dissertations and Theses. (UMI No. NQ63889).

Küçükaycan, D.(2018). Hesap verme sorumluluğu çerçevesinde belediyelerde performans raporlamanın performans denetim kriterleri açısından değerlendirilmesi, Yayınlanmamış doktora tezi, Eskişehir Osmangazi Üniversitesi, Eskişehir.

Laird, M. D., Perryman, A. A., Hochwarter, W. A., Ferris, G. R., ve Zinko, R. (2009). The moderating effects of personal reputation on accountability-strain relationships. Journal of Occupational Health Psychology, 14, 70-83.

Langhe, B. D., van Osselaer, S. M. J., ve Wierenga, B. (2011). The effects of process and outcome accountability on judgment process and performance. Organizational Behavior and Human Decision Processes, $115,238-252$.

Lanivich, S., Brees, J. R., Hochwarter, W. A., ve Ferris, G. R. (2010). P-E fit as a moderator of the accountability-employee reactions relationships. Convergent results across two samples. Journal of Vocational Behavior, 77, 425-436. 
Leithwood, K. ve Earl, L. (2000). Educational accountability effects: An international perspective. Peabody Journal of Education, 75(4), 1-18.

Lerner, J. S., ve Tetlock, P. E. (1999). Accounting for the effects of accountability. Psychological Bulletin, 125(2), 255-275.

Libby, T., Salterio, S. E., ve Webb, A. (2004). The balanced scorecard: The effects of assurance and process accountability on managerial judgment. The Accounting Review, 79, 1075-1094.

McCandless, H. E. (2001). A citizen's guide to public accountability: Changing the relationship between citizens and authorities. Victoria, BC: Trafford.

Menon, N., ve Akhilesh, K. (1994). Functional dependent stress among managers: A new perspective. Journal of Managerial Psychology, 9, 13-23.

Mero, N.P. ve Motowildo, S.J. (1995). Effects of rater accountability on the accuracy and the favorability of performance ratings. Journal of Applied Psychology, 80, 517-524.

Mitchell, T. R. (1993). Leadership, values, and accountability. In M. M. Chemers, \& R. Ayman (Eds.), Leadership theory and research: Perspectives and directions ( p. 109-136). San Diego, CA: Academic Press.

Mitchell, T. R., Hopper, H., Daniels, D., George-Falvy, J., ve Ferris, G. R. (1998). Power, accountability, and inappropriate actions. Applied Psychology, 47(4), 497-517.

Møller, J. (2009). School leadership in an age of accountability: Tensions between managerial and professional accountability. Journal of Educational Change, 10, 37-46.

Monks, R. A., ve Minow, N. (1991). Power and accountability. New York: HarperCollins Publishers.

Mulgan, R. (2003). Holding power to account: Accountability in modern democracies. Basingstoke: Palgrave.

Özcan, E. (2011). Türk kamu yönetiminde ve güvenlik hizmetlerinde hesap verebilirlik. Yüksek lisans tezi, Adnan Menderes Üniversitesi, Aydın.

Özen, F. (2011). Illköğretim okulu yönetici ve öğretmenlerinin görüşlerine göre okul geliştirme aracı olarak hesap verebilirlik. Yayınlanmamış doktora tezi. Ankara Üniversitesi, Ankara. 
Philp, M. (2009). Delimiting democratic accountability. Political Studies, 57(1), 28-53.

Roberts, K., Stout, S., ve Halpern, J. (1994). Decision Dynamics in Two High Reliability Military Organizations. Management Science, 40, 614-424. http://dx.doi.org/10.1287/mnsc.40.5.614

Romzek, B., ve Dubnick, M. (1998). Accountability. In: J. M. Shafritz (Ed.), The International Encyclopedia Of Public Policy And Administration ( 1, pp. 6-11). Boulder, CO: Westview Press.

Rosenblatt, Z. (2017). Personal accountability in education: measure development and validation, Journal of Educational Administration, 55(1): 18-32, doi: 10.1108/JEA-10-2015-0093

Royle, T., Hochwarter, W. A., ve Hall, A. T. (2008). The mediating effect of informal accountability for others. International Journal of Management and Marketing Research, 1, 1-22.

Salduz, E. (2013). Öğretmenlerin hesap verebilirliklerini öğrencilerin akademik başarısı açısından değgrlendirmeleri. Yüksek lisans tezi, Marmara Üniversitesi, İstanbul.

Schillemans, T. ve Bovens, M. (2011). The challenges of multiple accountability: Does redundancy lead to overload?. In M. J. Dubnick and H. G. Frederickson (Eds.), Accountable Governance: Problems And Promises (p. 3-21), Armonk, NY: M.E. Sharpe.

Schlenker, B. R., ve Weigold, M. F. (1989). Self-identification and accountability. In R. A. Giacalone ve P. Rosenfeld (Eds.), Impression Management In The Organization (p. 21-43). Hillsdale, NJ: Lawrence Erlbaum.

Schlenker, B. R., Britt, T. W., Pennington, J., Murphy, R., ve Doherty, K. (1994). The triangle model of responsibility. Psychological Review, 101, 632-652.

Scholten, L., van Knippenberg, D., Nijstad, B. A., ve De Dreu, C. K. (2007). Motivated information processing and group decision-making: Effects of process accountability on information processing and decision quality. Journal of Experimental Social Psychology, 43, 539-552.

Scott, C. (2000). Accountability in the regulatory state. Journal of Law and Society, 27(1), 38-60.

Scott, M., ve Lyman, M. (1968). Accounts. American Sociological Review, 33, $46-62$. 
Semin, G. R., ve Manstead, A. S. R. (1983). The accountability of conduct. A social psychological analysis. New York: Academic Press.

Siegel-Jacobs, K., ve Yates, J. F. (1996). Effects of procedural and outcome accountability on judgment quality. Organizational Behavior and Human Decision Processes, 65, 1-17.

Smith, J., Terry, D., ve Hogg, M. (2007). Social identity and the attitudebehavior relationship: Effects of anonymity and accountability. European Journal of Social Psychology, 37, 239-257.

Staw, B., ve Boettger, R. (1990). Task revision: A neglected form of work performance. Academy of Management Journal, 33, 534-559.

Tetlock, P. (1992). The impact of accountability on judgment and choice. Toward a social contingency model. In M. Zanna (Ed.), Advances In Experimental Social Psychology (p. 331-377). New York, NY: Academic Press.

Tetlock, P. E. (1985). Accountability: The neglected social context of judgment and choice. In L. L. Cummings, \& B. M. Staw (Eds.), Research In Organizational Behavior (7, p. 297-332). Greenwich, CT: JAI Press.

Tetlock, P. E. (1999). Accountability theory: Mixing properties of human agents with properties of social systems. In: L. L. Thompson, J. M. Levine \& D. M. Messick (Eds), Shared Cognition In Organizations: The Management Of Knowledge (p.117-138). Mahwah, NJ: Lawrence Erlbaum Associates.

Wagner, R. B. (1989). Accountability in education: A philosophical inquiry. New York: Routledge.

Yarnold, P. R., Mueser, K. T., ve Lyons, J. S. (1988). Type A behavior, accountability, and work rate in small groups. Journal of Research in Personality, 22(3), 353-360.

Yıldırım, K. ve Yenipınar, Ş. (2019). Okul yöneticilerine göre öğretimsel hesap verebilirlik olgusunun nitel analizi. Kastamonu Ĕ̆itim Dergisi, 27(1), 151-162. 


\section{Kaynakça Bilgisi / Citation Information}

Erdağ, C. (2019). Öğretmenlerin hesap verebilirlik çevreleri: Teorik bir çözümleme. OPUS-Uluslararası Toplum Araştırmaları Dergisi, 11(18), 2728-2759. DOI: 10.26466/opus.559784 